CATALAN REVIEW

Catalan Review

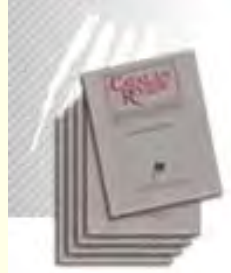

You are accessing the Digital Archive of the Catalan Review Journal.

By accessing and/or using this Digital Archive, you accept and agree to abide by the Terms and Conditions of Use available at http://www.nacs-

catalanstudies.org/catalan_review.html

Catalan Review is the premier international scholarly journal devoted to all aspects of Catalan culture. By Catalan culture is understood all manifestations of intellectual and artistic life produced in the Catalan language or in the geographical areas where Catalan is spoken. Catalan Review has been in publication since 1986 .
NORTH

AMERICAN

CATALAN

SOCIETY
Esteu accedint a l'Arxiu Digital del Catalan Review

A l' accedir i / o utilitzar aquest Arxiu Digital, vostè accepta i es compromet a complir els termes i condicions d'ús disponibles a http://www.nacs-

catalanstudies.org/catalan_review.html

Catalan Review és la primera revista internacional dedicada a tots els aspectes de la cultura catalana. Per la cultura catalana s'entén totes les manifestacions de la vida intel lectual i artística produïda en llengua catalana o en les zones geogràfiques on es parla català. Catalan Review es publica des de 1986.

\title{
Catalan Christmas: Nourishment in Catalan Literature Alain Verjat
}

Catalan Review, Vol. III, number 2 (1989), p. 151-171 


\title{
CATALAN CHRISTMAS: \\ NOURISHMENT IN CATALAN LITERATURE
}

\author{
ALAIN VERJAT
}

First of all, the subject of our meeting has plunged me into severe meditations. Nourishment! Should I begin by talking about manducatory archetypes, about sexual and digestive descent, about the digestive scheme or the system of the pork? How should we centre a subject which is so familiar, so well known and, after all, so trivial, on our favourite level, namely that of the imaginary. Everyone would certainly rub his hands.

Yet it seems to me that a talk of this sort, like all those organized by the CRI, should require deeper consideration from us. In my opinion, a means of achieving our aim would be, among others, trying to track the archetype, however hidden it may be, both in the dishes we are offered and in literature, the topic I am going to deal with. And yet coherence between literary and nourishing cooking is required to make the hypothesis reliable. We need - to say it in a rather hasty way - to cook up in the same pot both the earthly nourishment and the spiritual one, so that the thing we are about to eat becomes the same as what we read, imagine and dream. This is therefore my starting point. Admitting that the writer's concern is not sustained primarily by his fidelity to traditions and folklore but, on the contrary, by the way he applies them to achieve their transformation, all the questions held in common by literature and nourishment stand as a part of an unassailable redoubt supporting

I It is my intention to pint out the traditional and the ancient background sometimes lost in the midst of time. My examples, however, are recent. I have chosen on purpose the literary echoes from the last fifty hundred years of Catalan poetry -at that time the most rich and varied- so as to elucidate my hypothesis. Time does not matter... 
the sound unity of the Imaginary and probably its universality; but this is what this talk should clarify.

Furthermore, as a spokesman for the GRIM of Barcelona. I would like to bring forward nourishment from beyond the Pyrenees in order to demonstrate here the vitality of the Imaginary background existing there. It has been necessary to work on a corpus of ours which could be likely, however modestly, to improve the works of Grenoble. I must confess at once my incompetence in the field I have chosen for this talk or, in any case, in the specialized field of Catalan literature. It may be claimed instead that my skill at gastronomy as well as my opinions related to it are at least on a level with any other's. Since I am still exposing my limitations, my reminders, purposes, gratitudes and such other preambles, I will add, so as to end with all those questions that are likely to bore you, that I have had very little time to develop the exhaustive, definitive and masterly work that you deserve and that you may be expecting. I have found myself compelled to limit severely the domain of my research, primarily to focus better on the details, furthermore because, to put it plainly (and he or she who, like me, are daily overcome by any administrative tasks will be sympathetic), it is the most convenient way to make a presentable work without having much time.

I am going to outline therefore Christmas nourishment in the Catalan lands, its traditions and its related symbols, and how this finds a correspondence in literature. My intention is to bring to light a certain number of constants you may consider very interesting.

In Catalonia, as in most places, Christmas time occurs in the winter solstice, that is, when nights are the longest of the year and days are the shortest. This leads us directly to primitive man and his fear to darkness forcing him to exorcise the night. This first opposition between light and darkness will reveal itself in the subject we are dealing with, and will produce - in most ancient traditions - all the ritual concerning the sun 
worship comparably or symmetrically related to those of the summer solstice, around the Midsummer Day bonfires. Here are some literary examples tending to explain this sensibility in the images of darkness, chaos, night and storm, and of everything that can be considered as hostile to man. In order to mantain accuracy and not to deprive you of the charms of the original text, I provide the reference in Catalan and then the translation.

\section{Nadal arriba amb temporal. Batega \\ l'avidesa de joia, temorega. \\ Nadal arriba amb temporal...2}

This time of growing fear -Advent time- is, as we shall see later, a time for fasting. Shortly Christmas will become the time of light and of the clairvoyance that sees clearer in the night than in the day:

\section{Tenebres de Nadal, no són tenebres; més hi veig en vosaltres que no en el dia clars}

In a Christian context, which is certainly later in time than the items I am about to mention, we find that those very images are recurrent. In Joan Salavedra's poem, Poema del Pessebre, of which Pau Casals made an oratorio, the mule in the manger takes the child Jesus for a baby mule and nevertheless says:

\section{Sembla un sol, posat damunt la palla 4}

As for the ox, thinking that the newborn is a little calf, he declares sententiously:

2 Sebastià Sanchez-Juan, Presagis de Nadal.

3 Joan Maragall, "Els núvols de Nadal", Disperses, 1904.

4 Joan Alavedra, Poema del Pessebre, Barcelona, 1958, p. rr8. 
Però fa una claror

i una resplandor

que tot ho il.lumina...s

Darkness summons light, but it summons life, revival and fecundity as well. When the images become more complex, when the moon enters the dance (and I will later discuss the sardana and the agrarian rituals), it is the round womb of Mary that becomes the symbol for light:

Enllà dels temps, el cel s'entenebria i sols lluien nines de serpent.

Contra les ombres de la mort, Maria sorgeix vestida amb nacres d'Orient.

Avança, i tot ho centra i ho concentra en la sagrada corba del seu ventre, esperes i paisatges, terra i cel...6

In a second stage, Christmas time also coincides with hunting rituals and festivals - bear and wolf hunting above all. Those animals are of an unpleasant sort to man and have long stood for several kinds of demons, the evil spiritis that must be chased out from this world so that the world can continue. Bear and wolf hunting is therefore closely connected with the inversion and cycle ceremonies.
El llop no gosa
moure brogit
Fuig el diable
La nit és dia.
Jesús és nat.7

s J. Alavedra, ibid., p. n8.

${ }^{6}$ Climent Forner, "Poemes d'Advent, I", Els únics mots, Poemes, 1964

7 Guerau de Liost, La ciutat d'Ivori, 1918, "Nit de Nadal”. 
Everywhere, Christmas time is also the period in which festivals concerning winter sowing and fecundity rituals are celebrated in order to awaken nature from its apparent sleep and to make the dead grain germinate. But before talking about the Christmas menu we should simply approach the nourishment par excellence: bread.

Before entering into details, I must insist on the well known phenomenon that fits old traditions into Christianity thus making things a little more complex (even though less than it seems at a glance) and providing sufficient ancient symbolic traditions to discern the most important images of the archetypes. With regard to fecundity, for example, (and it is not my intention to shock anybody for these are the facts) it can certainly be observed that there are four barren figures gathered round the solar infant Jesus in the scene of the Manger: the ox, the she-mule (or the he-mule, depending on versions, but never the ass of the French tradition), Joseph (I will not insist) and Mary. It is as if the barreness of the group was there only to make evident the bright fecundity they are surrounding.

The question of Christmas fecundity is prior to the Christianization of the festival as well as to its spiritualization, and it will bring us back to the nourishing questions. For Christmas, as I have already pointed out, marks the end of hunger (for it is the winter season) and/or of the fasting established by the Church in the Middle Ages. There was such a thing as the Advent Fasting, and this will explain the points that Lent, Shrovetide and Easter had in common at the time.

That is why Christmas time is presided over by the wish of representing the erradication of hunger in all senses. The traditions in Catalonia serve as an evidence to this. ${ }^{8}$ There is a Christ-

${ }^{8}$ Here, as well as in the essential parts of this work, I owe my sources to Joan Amades' Costumari. In order not to make the text heavy with notes, it is taken for granted that I borrow my information from the pages that correspond to December and January, this work being classified day by day. All the later authors have only repeated Amades' work. 
mas for the birds, which find little cribs full of corn placed on the windows that day. There is also a Christmas for the vagrant, who finds a table furnished with the most exquisite food so that he can eat as much as he likes at the entrance of isolated farms or, formerly, in the yards of castles. There is still another image that completes that of the satiated stomach. Christmas is also a time to be at home, sheltered and warmed by the fire. It is a festival, then, in which the family is gathered together in its secular shelter forming a warm privacy, the feast being but the second representation.

Per Nadal, cada ovella a son corral.

This proverb hints the necessity of having a home before sitting at the table. That is why the Midnight supper on Christmas Eve is so widespread in Catalonia, as everywhere, mainly because in the cities people do not go so much to the midnight mass nowadays and yet some kind of celebration is needed at that time; but Christmas day involves essentially a family feast in which the distant relatives are often gathered together in a multitudinarious supper, a feast which has not yet been distorted by the question of presents and toys.

In the same spirit of charity tinged with generosity and abundance, Christmas time was until the last century the time of presents given in kind; the only reminder of which are the business gifts. 9 Thus every artisan gave his best, richest and most refined products as a present to his customers. The bakers and the pastry-cooks, for example, made a white and sugared bread; the spaghetti makers distributed their plumpest products under the name of - it was the least that could be expected - "monk's

9 They are the splendid baskets full of canned foods and drinks, all adorned with lots of ribbons, garlands and floss silks. In the middle of the basket the dried leg of a pig stands out very often against a cascade of cans, of all sorts of wines and liquors and of "torrons". 
fingers" and still of archdeacon's macaroni. Well-off families also practiced the Christmas alms, which consisted in making forty big nine-pound loaves of bread which were delivered to forty beggars. Besides, asylums were given loaves of bread for forty days. This figure highlights the similitudes with Lent, retreat and fasting. In general, the inferiors used to give this kind of presents to their superiors, as if, in the festivity of the return, they were giving them back what they had been given; here are the cycle images we were talking about. Scavengers provide the best example, since they made presents to the noble and bourgeois families, mainly the vegetables of which boiled beef would be made up, and which I am presently going to deal with. But why? At that time scavengers were not the sad immigrants of today. There was not so much waste that is difficult to collect and recycle. In return they had plenty of dung. That is why they tended to become market-gardeners. And their presents consisted mainly of bunches of leeks and celery that were to scent the rich broths prepared for the Christmas banquet, in proper repayment.10

Christmas is mainly the festival of this first, primary, essential and cereal (with regard to Ceres, obviously) nourishment: bread. In Joan Alavedra's poem of which I am presently going to talk about, the shepherds meet a worker on their way to the Manger and they invite him to join them. He answers:

\author{
He d'acabar la feinada \\ que tinc a llaurar $i$ sembrar \\ batre el blat, moldre la grana, \\ pastar-la i coure el bon pa \\ rodó $\mathrm{i}$ de crosta daurada...."
}

10. There are many examples in this particular case. Godfathers gave a pie made of baked bread to their godsons as a Christmas present which was called "rabasa". It was human-shaped, with feet and legs but without arms. Afterwards, it was changed into a monkey with an egg (a hard-boiled one!) in its mouth.

"I Alavedra, op.cit., p. 43. 
He has been told by an angel: "Alça't de seguida/ Juny els bous/ i llaura que llaura/ fins que et digui prou....

It is the same bread we find in rituals, mainly in agrarian ones, which reproduce a kind of Eucharist within the privacy of the farm. After having supper, on Christmas Eve, three white tablecloths of the finest thread are laid and thirteen loaves of bread are placed on them. The head of the household says grace, takes a piece, then kisses it and keeps it to him in the belief that it will not get spoiled in the whole year. The seamen of the family, the fishermen, take the piece along. In case of storm the bread is supposed to calm down the most raging waves once thrown to the sea. The cycles of Nature are, according to the imaginary, stronger than the bursting forces of chaos.

Before the gastronomic habits were leveled, so that everybody shared the same celebration regardless of his economic plight, each profession celebrated the festival behind closed doors, so to speak, that is, with the products of their personal industry. The Christmas of the shepherds was not the same, as far as the nourishment is concerned, as the one celebrated by the fishermen or the bourgeois. But the menu was exceptional everywhere, even if it was not inspired in the luxury and the unbridled consumerism of present life. Up in the mountains, for example, people ate early thistles, and did not eat them in any other period of the year. Shepherds ate their most creamy, round and fine cheese before slaughtering the lamb, and also medlars, prunes and lots of fruits and milk food that contrast with the dearth of mid winter. According to this, Christmas is an image and a practice of ripeness even though it is not the fitting season for it. Here, literature is still more explicit than folklore:

Com si hi plogués or

lo blat s'engroguia,

$i$ el pastor guarit

canta d'alegria

12 Id., ibid., ibid. 


\author{
veient que l'anyell \\ jugava i paixia. \\ Beneix la vall: \\ la vall refloria... ${ }^{13}$
}

A popular song says that the infant Jesus will be given, in order to please him, "panses $\mathrm{i}$ figues i mel i olives, panses i figues i mel i matón.44 Even Alavedra's poem shows a shepherd who lays down a currant-bush branch full of red berries beside Jesus.Is So here is the red colour, but I will return to it later; it will lead us to the subject related to the blood and the sun, to slaughter and to the heat of life. In a general sense, Christmas links nourishing images of fecundity and of revival. There is fecundity because of the fact that revival also exists. And there is revival because the festival denies the apparent death of nature. Unexpectedly we find that there is spring in the middle of the winter, as in the famous poem of Supervielle in which a blossoming apple-tree is created:

$$
\begin{aligned}
& \text { D'ençà que ell (Jesus) és nat } \\
& \text { la terra s'enjoia; } \\
& \text { els monts més nevats } \\
& \text { de raigs se coronen } \\
& \text { Tots els ocellets } \\
& \text { ixen de la brossa } \\
& \text { com si fos l'estiu } \\
& \text { volen que més volen... }
\end{aligned}
$$

13 Jacint Verdaguer, Jesús-Infant-Natzaret, 1890.

${ }^{14}$ Raisins, figs, honey and olives (bis) and cream cheese.

15 "Un pastor:

- jo vull donar-li aquest ram

que està tan ple de groselles..."

Alavedra, op.cit., p. 145.

16 Milà i Fontanals, Poesies, 1895. 
In a later writer of quite a different inspiration, nearer the Valéry of the Album de vers ancien, we find again an image that is often reminiscent of Supervielle, great creator of wonderful isles in the middle of the ocean. He is Josep Carner, who in his "Balada de Nadal per cantar-la als pirates del mar" gives the following passage:

\author{
Entre la neu senderegen les flors; \\ l'aire és ple d'ales i d'ales; \\ sota el cobert hi ha la Dama i l'Espòs \\ i un infantó... \\ juga amb ocells i amanyaga primales. \\ Entre la neu... ${ }^{17}$
}

The image of abundance, of spring in the middle of winter, of the reactivation of life's nourishing nature is present in very different fields. First, it is to be detected, I think, in the regular practice of the sardana in Catalonia. The sardana is much more than a popular dance, preserved in formaldehyde and naphtaline and brought up to date once a year. It is normally performed every week, very often anyway, and in spite of the fact that the population is more and more mingled and that people go to discothèques, it still brings young and old people together, the old who feel young and the young who feel old, in village and two squares. It is not a Christmas dance - since Christmas is, as I have already said, a festival characterized by privacy - but it has a symbolism that converges with most of the elements I have just exposed. As you know, the sardana is a circular dance, rather slow at the beginning, quite formal, enlivened in its central part and returning at the end to the initial theme. Many anthropologists have demonstrated it is based on a lunar dance; it must be specified that it is so because it is a dance which intends the activation of the vegetation growth. In 
certain villages, and in Christmas time, spinning tops are played. We must say something about the "zambomba" in the same field of symbolic musical motion; it is a rather rudimentary instrument made of a soundbox covered with leather to which a stick is attached. The sound is produced by rubbing the stick from top to bottom. The "zambomba" is played in the street, on the way to and from the church or singing in groups. It is just the motion that causes music I am concerned with and I must say it is a motion that stirs nature. It is similar indeed to the one by which fire is produced and also to the motion made to prepare the "aiioli" or to crush almonds in the mortar. Almonds, as we shall see, play an important part in Christmas sweets; as for the "aïoli", which is served mainly with meat and grilled fish, there was a time when it was one of the most traditional nourishments of Advent time. It is with a great caution that I would like to suggest very hastily -in case there should be someone with a far better knowledge of the item- a hypothesis likely, in my opinion, to be attractive. It seems to me that Christmas involves a certain sense of vertical direction, a kind of vertical meaning of abundance or fo manna, as you prefere. I have been wondering if the motion of the "zambomba", which is of course a rhythmic motion just like that of the churn, is not as well a vertical motion, going from top to bottom, as if linking heaven and earth. Thus, Father Christmas, Santa Claus or the infant Jesus (in Spain the Three Wise Men and their camels), before bringing to the children the horrible plastic toys offered by the consumer society, bring them sweets; and the more uncommon, the better appreciated they are. There are several villages in Catalonia where it is the Virgin Mary who comes down through the chimeny. But, surprisingly, she brings nothing. In return, a layette is left to her so that she can change the infant Jesus clothes together with all sorts of loaves of bread in special shapes. I have been led to this hypothesis concerning vertical generosity and connecting heaven and nourishment by two lines of Sebastià Sanchez-Juan: 
Per la xemeneia sense fons

puja i baixa el misteri entre el Cel i els fogons ${ }^{18}$

There were many churches all around Catalonia where sweets and dried fruits were thrown out to the children in the organ loft. In order to increase the mystery of the thing, certain churches even had a conduit or a pipe that was to be used only to that purpose.

If you find it hard to agree that there is a vertical sense to which the cooking and the sacred are closely related, it will be admitted at least that Christmas nourishment acquires in this way a more defined sacred character.

I would like to talk now about one specific tradition existing in Catalonia, in which the symbolism provides the image of the blooming stick. It is the festival of the "tion" practiced generally on the Christmas Eve just before going to the Midnight mass. The "tió" is but a log and owes its name to the fact that it is burned in the fire-place. The festival consists in getting a stick and hitting the log (this is called "fer cagar el tión - to make the log excrete) which is generally covered with a blanket in order to conceal the necessary conjuring trick. Then all sorts of candies and little presents "come out" from it. Provided Bachelar's invitation to dreaming of images, we must represent the burning log being hit - who has never done it? with the poker in order to make it spark, fire and light magic thus adapted to a range of sweetness; the log stands therefore as a digestive and sexual womb where happy descent brings about abundance in times of hunger. On the origin of this festival converge two traditions concerning two different kinds of beliefs. Ancestry is represented here by this common log, the head of the household used to call down a blessing on it before letting the $\log$ in and make it burn. The log also stands for the indulgent grandfather, the one who gives sweets. Here again we

18. Cua de gall (1929), "Nadal". 
find the fire worship with solar connotations together with the nourishing and fecundity rituals. The ashes from the log were formerly mixed up with the seed before sowing time and were thrust together. Around the winter fire, it is a Christmas fire as we can see, things can go even further and establish a national identity, that is, a sense of fatherland, as in these lines from Miquel Costa i Llobera:

\section{Què hi fa si puja el fred? Serà més dolça la foguerada dins la llar dels avis, que amb caliu volgut mantén i eleva el culte de la pàtria. ${ }^{19}$}

But it is about the time to deal with serious things, I mean with the Christmas menu itself of which the former considerations were but a foreword. Somehow concerned with the works of Lévy-Strauss and so as to understand that which is inherent in the Christmas cooking, I would like you to consider that there are two different kinds of cooking in Catalonia depending on the season. There is a summer cooking to which fine weather and open air are essential; it is a typical nomadic cooking, so to speak, based on the use of wood coals (the best are vinebranches, indeed) and also on the grill and the slate ("la llosa" being rubbed with garlic and olive oil mostly in the mountains). It is the cooking of the wonderful mutton chop orgies, as well as of the greasy sausages and of the "escalivada", this one made of such vegetables as peppers, eggplants and marrows all grilled directly on the live coals. From the very first days of January is celebrated in the country the festival of the "calçots", a vegetable hibrid halfway the soft onion and the leek. They are only eaten around these days, from January to Easter. They are grilled - we could better say carbonized - on a tile placed over live coals. Then they are pressed just like a toothpaste tube in order

19 "Entrada d'hivern", Horacianes, 1906. 
to take te soft inside out of the blackened peel; they are dipped into a sauce made of vinegar, pounded almonds, tomato and oil, and so they are swallowed down more or less greedily in a vertical position that forces the eater to be looking at the sky. Incidentally, the same motion concerning the disgestive descent is found in the way people drink out of the "porró". This kind of open air cooking contrasts with the Christmas one, which is an inside cooking based on warmth, on the oven and on the stew.

Meats are the main nourishment in Christmas time. Eating meat in Christmas is almost obligatory in Ibiza. In Girona, where there is plenty of cattle, three heads are bought and slaughtered around Christmas time, on the first of January and around Epifany. As for the Christmas presents of which I have already talked about, people used to give away poultry to the so-called "artistes", that is, to the liberal professions: the doctor, the chemist, the priest and the teacher. The present depended on the services received from them during the year. As for the teacher, it was often the only day of the year on which he could eat meat ("més pobre que un mestre" as it was said); meat was to be eaten fully, because it was thought highly improper to give away the surplus meal or even to change it for any other nourishment.

As it has been said before, meat stands for an exceptional nourishment as well as for abundance, but it also represents several concurrents traditions, such as hunting, the sleeping nature being fecundated by slaughtering, and the struggle against evil spirits. As regards hunting, it was thought that wolves and bears lived on meat for three months, then on blood for another three months, and on water and wind till the end of the year. This last term, that of Christmas, was therefore the appropiate to giving chase to them. That is why hunting, however scarce it is today, was organized at that time, and it usually took place on November. The struggle against evil spirits may be illustrated from the tradition that consists in craming a dog (or a cock), 
normally a wandering one, and in hitting the animal so as to make it run away when it has plenty of food. The same applies to the rooster, but here it was beaten to death, then it was carried to the church for the midnight mass (that in Catalan is called "missa de gall») that was somehow presided by the cock placed on the main altar. Of course, these two traditions were not the most widespread, and the essential point seems to be the overabundance of meat as a consequence of excessive animal slaughtering. That which is slaughtered is the sacred animal in its tender age, that is to say, the lamb, the piglet, but also the first fruits, the first winter wheat and the white bread or the "coques",20 After the Annunciation,
Un pastor agafa un pollastre
l'altre, un anyellet ben $\mathrm{fi}$,
l'altre un xai de la ramada,
l'altre un gall d'indi polit.
De mel una gerra plena
s'emporta el que és més petit ${ }^{21}$

The pig evokes no literary reminicences. Let's say it is not highly estimated for it is too material and usually means greediness and voracity; it is too evident a symbol for the digestive whirlpool that swallows everything down. However, it is just in winter time that the pig slaughtering is made, and that people eat the first products coming from it: sausages, black pudding, bacon, cracklings. Lambs are seldom mentioned for they are perhaps more closely associated with Easter. Conversely, the rooster is not so well considered because of the toughness of its flesh, and yet it is the animal people talk most of. Before dealing with the cock, let's say what the Catalan Christmas menu

20 The "coca" is a sort of pizza, either sweet or salted, depending on its ingredients. In the Balearic Islands it is often made of vegetables and pork. For Christmas, however, it is normally sweet all around Catalonia.

2t Joan Alavedra., op.cit., pp. 2I-22. 
made of (I must say this menu comes after a forty-day fasting, I mean used to come...). The Christmas spread begins with a potful, "l'escudella", made of vegetables, and with the "four mendicant orders", that is to say, St. Anthony's pig, St. Luke's ox, St. Peter's chicken and St. John's lamb, in addition to the "galets", a sort of a very big soup noodle.

It was thought that the saints of these four meats protected those who ate them all the year, and that if the housewife missed one of them, the involved saint got angry because his meat had not been eaten and avenged himself on the guests until next Christmas. Broth and vegetables were eaten first, in addition to meatballs or a big piece of minced meat which is called "pilota" (ball, that is to say, womb). Afterwards, we have meat. Then, the poultry offals, gizzards and liver, all dipped in sauce. But the chief item of the meal was the rooster, though it is often replaced today by capon, for it is fatter and less tough, or by turkey, this one, however, only known since Columbus' journeys. It was a sacred animal in Mexico (hence "gall d'indi)). That is why it has substituted the traditional cock. Whether turkey, capon or cock, the essential thing is that it is stuffed with sausages, pork's filet, prunes, pears and pine nuts. One of the pleasures at table consists in talking about the food ready to be eaten. The conversation deals with the purchase of the living animal, with the troubles due to its transport, with how it has been killed, plucked and cooked. Then the animal is described and compared to that of the previous year. It is the housewife privilege to open the belly of the animal to show the wonders of its stuffing to the guests. And yet the task of carving the meat is performed by the head of the household. The symbolic implications of this Caesarean operation are quite evident, and I would insist on the subject if the animal were not a cock...! There seems to be nothing related to hermaphroditism. And yet we can talk about the combination of opposite functions, as far as the Christmas miracles and beliefs are concerned. It seems to me that the image of the cock has a wide range of symbolic senses, some of them very widespread. 
First of all, we can consider the rooster to be the solar animal that announces the beginning of the day with its crow, moving away thus the evil influences of the night, that is to say, of winter, of cold and of barrenness of the nature that seems to be asleep. The very same cock will symbolize the triumphant Christ after the Christianism, being then a kind of hybrid between he eagle (absolutely uneatable) and the lamb. But I would rather compare it (with regard to the Caesarean operation we have just seen) to what it stands for in the analysis of dreams: the joining of the chtonic forces on a level with personal life, spirit and matter being balanced in a harmonic unity.

It also stands for the spirit of growth, the life of nature par excellence, acquiring thus a sacred character. Formerly, only the nobility could eat its meat. It became later the favorite nourishment of brave people and, of course, of lovers.

Literary texts, which never deal with nourishment directly with regard to Christmas, are of great interest to us because they provide the specific meaning of the cock that presides at the Christmas table according to the Catalan Imaginary.

The firts image is the most simple as well, that of the cock breaking silence or cold:

Gall que canta, gel que es trenca ${ }^{22}$ $i$ el crit dels galls

com una pedra dins la calma d'un estany ${ }^{23}$

It is, then, a diairetic cock,

gall que cimeges en la torre més alta

heus aci en la partió de la nit i l'aurora...24

which is to be adorned with flames:

22 Joan de Segarra, Disperses, "Poema de Nadal".

23 Jordi Pere Cerdà, Obra poètica, 1967.

24 Joan Vinyoli, El callat, "Gall" (1956). 


\begin{abstract}
Els galls de nit filbasten matinades sobre el crestat de fems d'una era condormida; tenen plomes de foc que atuda un xic la lluna llepant la plaga roja $i$ viva de llur cant...2s
\end{abstract}

We find here again this constellation both of rooster and moon in the sad vision of the preliminaries of the Christmas banquet that Joan Salvat-Papasseit offers to us:

Els de casa a la cuina, prop del braser que crema, amb el gas tot encès han enllestit el gall. Ara esguardo la lluna que m'apar lluna plena $i$ ells recullen les plomes i ja enyoren demà.

Jesús ja serà nat.

Ens mirarà un moment a l'hores de les postres i desprès de mirar-nos arrencarà a plorar. ${ }^{26}$

So we come to the dessert. Here there is nothing shaped like a log: we have seen it before when talking about the "tion". Now we have "torrons", sweet "coques" with dried fruits, honey, almonds and "neules". After the meat comes the sweet food, after the sun comes the moon. This is a general sweetness: wine has to be sweet; it is a wine halfway muscatel and grenache. Spices were often added to it (nine measures of wine, a quarter of honey and a quarter of cayenne pepper): it was called "piment». That is how sun was produced in the body! Almonds, which are to be used so as to make the "torrons" (very late) are there because the almond tree blooms very soon and almonds are picked very late. Independently of the fruit's shape, the symbolism of which is well known, almonds and almond trees are there again to give evidence of the vitality showed by nature in the heart of winter:

25 Jordi Pere Cerdà, op.cit.

${ }^{26}$ L'irradiador del port $i$ les gavines (1921). 
I els ametllers floriran

al bell cor de l'hivernada

ells parlaran d'esperança. ${ }^{27}$

As for the "neules", the "coques" and the dried fruits, they all have to be included in the item of concentrated sugar. The "neules" are a sort of rolled wafers. Originally, they had the shape of a host and had votive drawings and texts. In Spanish they were also called "suplicaciones". Eating them was therefore a way of turning into reality the wish they expressed. Everything is communion here, as we can see, both in the community and in the totemistic sense. Eating them also made children laugh because they had to move the left hand thumb and forefinger at the same time in order to eat them; it was a little problem of coordination which recalls the harmony of contraries we have already seen in the course of this work.

Before "torró" existed, there was the "pinyonada", which was a dough made of flour, honey and pine nuts. These ingredients were considered as the only fitting for Christmas time. A remedy had been looked for during the plague of 1703 so as to overcome both the malady and the sadness of those who still were healthy. A contest was summoned among the confectioners. The rules pointed out that it was necessary to invent new sweets for Christmas, and that they had to be made of flour, honey and almonds. It was also necessary that products could be preserved for a long time and, finally, that one of them recalled the stone, and that another recalled the parchment. The winner of the first prize was a certain Pere Torró (it should had been so easy being called Peter) and gave his name to the product we know today. It was a mixture made of honey, almonds and pine nuts. It was also like a serpent's eye likely to ward off evil eye by all accounts. As for the second prize, it was won by

27 Apel.les Mestres, Tardanies, "La cançó de l'any nou". 
a certain Xercavins who had the bright idea of rolling the traditional "neules" as if they were parchments. The "torró has preserved its solid shape, though it is not always made of almonds nowadays. The "neules" are like our dried pancakes, but they are round.

As I have already said, this was all sprayed with wine. However, towards the end of the century, the industry of the sparkling wine became established in Catalonia. A good imitation of Champagne, it took over little by little the function of this wine. For those who, like me, think that the linguistic sign is not arbitrary, I will add that Saturn is, as everybody knows, the god that takes the place of the original Cronos. Well, then, the capital of the sparkling wine in Catalonia is a village called Sant Sadurni, "Saint Saturnine».

After all those spreads, there is nothing more natural, though it is very mitigated today, than having a rubicund face:
Però Nadal ens ha pintat el rostre amb un vermell precís i decidit $i$ ens dóna un sentiment de llar, de sostre, de terra, de nissaga i d'esperit. ${ }^{28}$

We already know this red color is nearer the sun and lifeblood than the nourishing excesses on a level with the imaginary. But it is of great interest to see how, in the idiosyncrasy of a country of which the poet gives evidence, the colors that good food give to the face are put together, in the very same xxth century, with the images of shelter, of nourishing land and of the race that keeps on living his own way. I hope, thus, to have demonstrated that, with regard to the Catalan imagery as well as to the Christmas nourishment and the customs related to it, there are two series that stand in contradiction to each other, Christianism having used them without changing anyt-

28 J. de Segarra, El poema de Nadal. 
hing essential. On one hand we have the solar series regarding fire, warmth, red color, blood, man and cock, and in a certain sense, also vertical direction and mountain. On the other hand, we have the moon - still with an evil connotation -, the blue color, cold and water, milk, woman and plain. As this second series can be adapted to the first one, the moon becomes an agrarian goddess regarding fertile feminity, and the emblematic cock of the Christmas banquet brings to light the treasures of its womb. Anyway, I would like to draw your attention to the fact that modern literature, being so little concerned with nourishment, talks poetically about Christmas with the same images folklore and tradition have preserved. 